Article

\title{
Inhibition of Tyrosyl-DNA Phosphodiesterase 1 by Lipophilic Pyrimidine Nucleosides
}

\author{
Alexandra L. Zakharenko ${ }^{1,+}{ }^{,}$Mikhail S. Drenichev ${ }^{2,+}{ }^{\circledR}$, Nadezhda S. Dyrkheeva ${ }^{1,+}$, \\ Georgy A. Ivanov ${ }^{2}$, Vladimir E. Oslovsky ${ }^{2}{ }^{\mathbb{D}}$, Ekaterina S. Ilina ${ }^{1}$, Irina A. Chernyshova ${ }^{1}$, \\ Olga I. Lavrik $1,3, *$ (D) and Sergey N. Mikhailov $2, *$ (D) \\ 1 Institute of Chemical Biology and Fundamental Medicine, Siberian Branch of the Russian Academy of \\ Sciences, 8 Lavrentiev Ave., 630090 Novosibirsk, Russia; a.zakharenko73@gmail.com (A.L.Z.); \\ elpida80@mail.ru (N.S.D.); katya.plekhanova@gmail.com (E.S.I.); chernyshova0305@gmail.com (I.A.C.) \\ 2 Engelhardt Institute of Molecular Biology, Russian Academy of Sciences, 32 Vavilova Str., 119991 Moscow, \\ Russia; mdrenichev@mail.ru (M.S.D.); georgyivanovk423@gmail.com (G.A.I.); \\ vladimiroslovsky@gmail.com (V.E.O.) \\ 3 Department of Natural Sciences, Novosibirsk State University, 2 Pirogova Str., 630090 Novosibirsk, Russia \\ * Correspondence: lavrik@niboch.nsc.ru (O.I.L.); smikh@eimb.ru (S.N.M.); \\ Tel.: +7(383)363-5195 (O.I.L.); +8(499)135-9733 (S.N.M.) \\ + These authors contributed equally to this work.
}

Academic Editors: Katherine Seley-Radtke and Luigi A. Agrofoglio

Received: 19 May 2020; Accepted: 9 August 2020; Published: 13 August 2020

check for updates

\begin{abstract}
Inhibition of DNA repair enzymes tyrosyl-DNA phosphodiesterase 1 and poly(ADP-ribose) polymerases 1 and 2 in the presence of pyrimidine nucleoside derivatives was studied here. New effective Tdp1 inhibitors were found in a series of nucleoside derivatives possessing $2^{\prime}, 3^{\prime}, 5^{\prime}$-tri-O-benzoyl-D-ribofuranose and 5-substituted uracil moieties and have half-maximal inhibitory concentrations $\left(\mathrm{IC}_{50}\right)$ in the lower micromolar and submicromolar range. $2^{\prime}, 3^{\prime}, 5^{\prime}$-Tri-Obenzoyl-5-iodouridine manifested the strongest inhibitory effect on $\mathrm{Tdp} 1\left(\mathrm{IC}_{50}=0.6 \mu \mathrm{M}\right)$. A decrease in the number of benzoic acid residues led to a marked decline in the inhibitory activity, and pyrimidine nucleosides lacking lipophilic groups (uridine, 5-fluorouridine, 5-chlorouridine, 5-bromouridine, 5-iodouridine, and ribothymidine) did not cause noticeable inhibition of Tdp1 ( $\left.\mathrm{IC}_{50}>50 \mu \mathrm{M}\right)$. No PARP1/2 inhibitors were found among the studied compounds (residual activity in the presence of $1 \mathrm{mM}$ substances was $50-100 \%$ ). Several O-benzoylated uridine and cytidine derivatives strengthened the action of topotecan on HeLa cervical cancer cells.
\end{abstract}

Keywords: nucleosides; DNA repair; tyrosyl-DNA phosphodiesterase; Tdp1 inhibition; topotecan

\section{Introduction}

DNA repair systems are resistant to the action of chemotherapeutic drugs and ionizing radiation, and therefore the beneficial effect of antitumor therapy depends on the effectiveness of DNA repair systems in tumor cells. Accordingly, targeted inhibition of DNA repair enzymes can increase the effectiveness of chemotherapeutic drugs used in clinical practice and may enable reducing their dose, which in turn can decrease the overall toxicity of treatment [1-8]. A number of enzymes and protein factors are involved in DNA repair [9-15]. Poly(ADP-ribose)polymerase 1 (PARP1, EC 2.4.2.30)—a key regulator of DNA repair mechanisms-is the most studied pharmacological target for the creation of targeted drugs [16]. Four PARP1 inhibitors (olaparib, rucaparib, niraparib, and talazoparib) are used in clinical practice for the treatment of ovarian cancer.

Among promising targets is the enzyme tyrosyl-DNA phosphodiesterase 1 (Tdp1), which is considered an important target for the antitumor therapy based on topoisomerase 1 (Top1) inhibitors [17]. 
Tdp1 plays a key role in the removal of Top1-DNA adducts stabilized by Top1 inhibitors such as camptothecin and its clinically relevant derivatives. The catalytic action of Tdp1 is the hydrolysis of the phosphotyrosyl bond between the $3^{\prime}$ end of DNA and a tyrosine residue of Top1 in a stabilized Top1-DNA complex, with hydrophobic interactions playing an important part in the binding of Tdp1 to the Top1-DNA complex [18]. The literature describes Tdp1 inhibitors of various structures based on different classes of natural and synthetic compounds [3,4]; these inhibitors have half-maximal inhibitory concentrations $\left(\mathrm{IC}_{50}\right)$ in the range $0.015-10.000 \mu \mathrm{M}$. Recently, a novel group of $\mathrm{Tdp} 1$ inhibitors effective in the submicromolar range of concentrations was found among disaccharide nucleosides with lipophilic groups [19]. The current work represents a continuation of our earlier studies on the inhibition of DNA repair enzymes by nucleoside compounds [19-24].

\section{Results}

\subsection{DNA Repair Enzyme Inhibition}

To study the inhibition of the DNA repair enzyme by nucleoside derivatives, a number of 5 -substituted derivatives of $2^{\prime}, 3^{\prime}, 5^{\prime}$-tri-O-benzoyluridine were synthesized according to the procedures elaborated earlier by Vorbrüggen and coworkers [25] and by Prasad and coworkers [26] (Scheme S1, Supplementary Material).

Previously, we designed a real-time oligonucleotide biosensor based on the capability of Tdp1 to remove fluorophore quenchers from the $3^{\prime}$ end of DNA [27]. The single-stranded substrate was a 16-mer oligonucleotide containing both a $5^{\prime}$-FAM fluorophore donor and a quenching $3^{\prime}$-BHQ moiety. When the quencher is removed by Tdp1, FAM fluorescence flares up and can be detected by a fluorimeter. Fluorescence intensity diminishes in the presence of an inhibitor; curves of the obtained $\mathrm{Tdp} 1$ activity versus inhibitor concentration can be used to calculate $\mathrm{IC}_{50}$ values. The results of the Tdp1 assay for nucleoside derivatives $\mathbf{1}$ and $\mathbf{2}$ are shown in Table 1 . We also investigated some structurally related compounds obtained by previously developed methods $[25,26,28]$; these compounds feature a modification either in a carbohydrate or heterocyclic moiety (Table 1 ).

Table 1. Inhibition of Tdp-1 by nucleoside derivatives.

\begin{tabular}{ccccc}
\hline Cmpd & & & \\
\hline 12 & & & \\
\hline 16
\end{tabular}


Table 1. Cont.

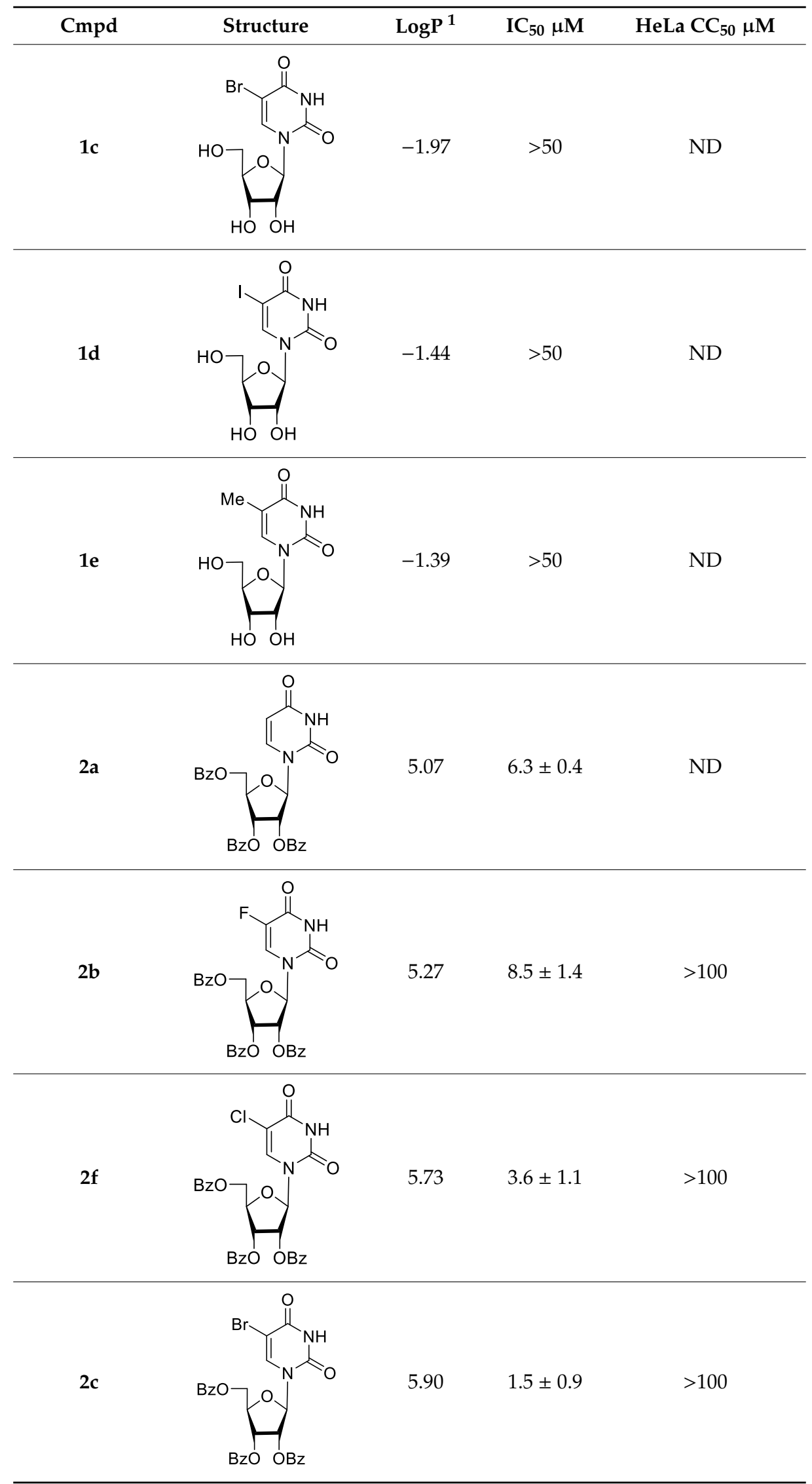


Table 1. Cont.

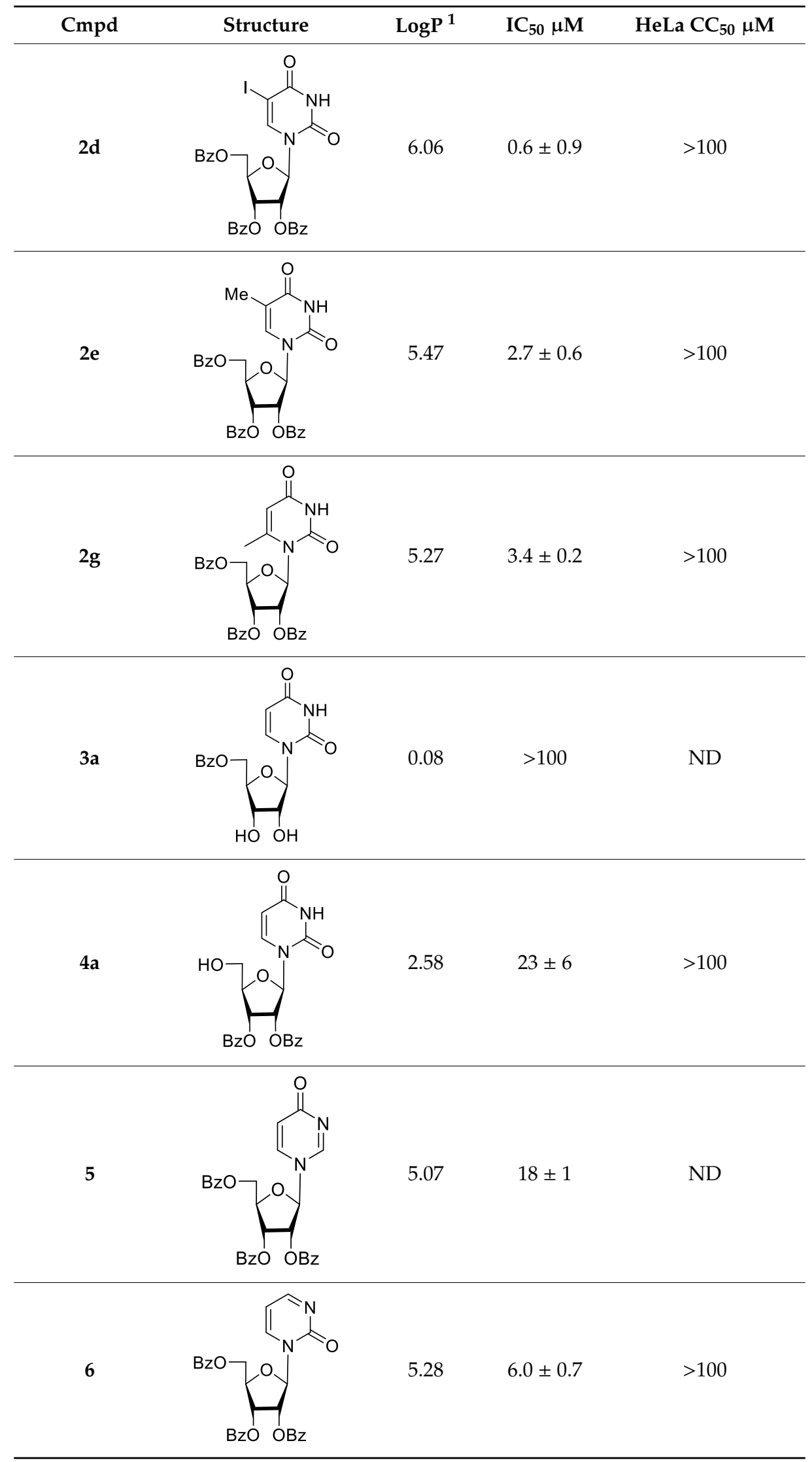


Table 1. Cont.

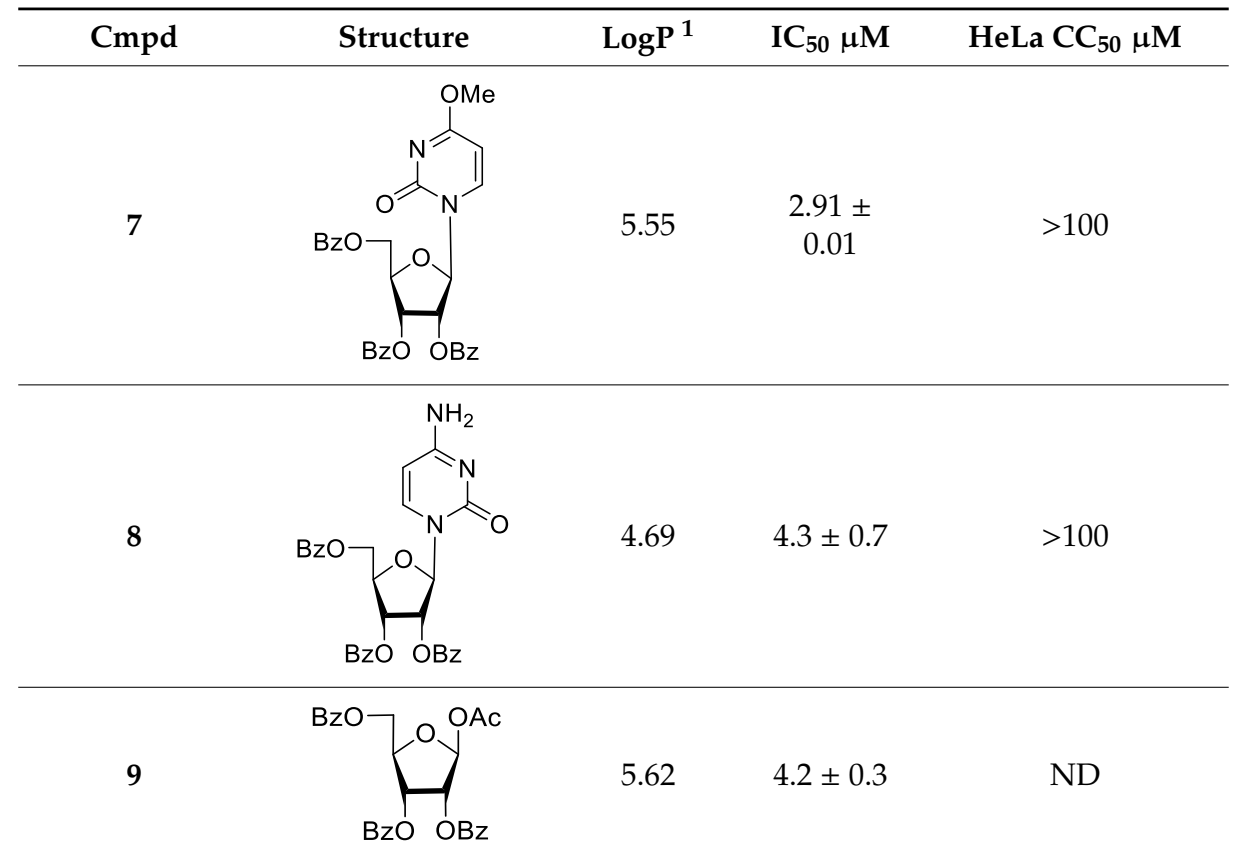

${ }^{1}$ The values of the partition coefficient of the compounds between the 1-octanol-water phases $(\log \mathrm{P})$ were calculated using the Instant J. Chem. (ChemAxon $\left.{ }^{\circledR}\right)$. ${ }^{2} \mathrm{ND}$ - not determined.

In addition to the effects on Tdp1, we tested the effects of the lipophilic nucleosides on DNA break sensors poly(ADP-ribose)polymerases 1 and 2 (PARP1 and PARP2), in a test system based on tritium-labeled $\mathrm{NAD}^{+}$[20]. None of the tested nucleosides caused significant inhibition of either PARP1 or PARP2 (residual activity in the presence of $1 \mathrm{mM}$ substances was $50-100 \%$, data not shown).

\subsection{Cytotoxicity and Sensitization of Tumor Cells to the Effect of Topotecan}

\subsubsection{Cytotoxicity}

We evaluated the cytotoxicity of compounds that showed a Tdp1-inhibitory activity as well as their impact on the cytotoxic effect of topotecan. First, we assessed the toxicity of the compounds to HeLa cells (cervical cancer cells). Analysis of the intrinsic cytotoxicity of the compounds was examined in the EZ4U Cell Proliferation and Cytotoxicity Assay (Biomedica, Austria). The tested compounds were added to the medium (the volume of added reagents was 1/100 of the total volume of the culture medium, and the amount of DMSO (dimethyl sulfoxide) was $1 \%$ of the final volume), and the cell culture was monitored for 3 days. Control cells were grown in the presence of $1 \%$ DMSO. Intrinsic cytotoxicity of the compounds was either absent or negligible at concentrations up to 100 $\mu \mathrm{M}$ ( $>80 \%$ live cells) with the exception of compounds $\mathbf{2 b}, \mathbf{2} \mathbf{c}$, and 7 , in the presence of which, at a concentration of $100 \mu \mathrm{M}, 30-45 \%$ of the cells died (Table 1 and Figure 1).

\subsubsection{Tumor Cell Sensitization to Topotecan}

To study the influence of the inhibitors on the cytotoxic effect of topotecan, the latter from the manufacturer ACTAVIS GROUP PTC ehf. was used. To select a nontoxic but effective concentration of the nucleoside compounds, we investigated their cytotoxicity in the presence of $2 \mu \mathrm{M}$ topotecan (concentration causing the death of half the HeLa cells). Three independent cytotoxicity assays were performed with each inhibitor in combination with topotecan. For the cells treated with a nucleoside derivative alone, values in the control wells treated with $1 \%$ DMSO were set to $100 \%$ viability. For the cells treated with a combination of the drugs, the viability of cells treated only with topotecan was set to $100 \%$. Topotecan significantly ( $p=0.05$, Mann-Whitney $U$ test) enhanced the cytotoxicity of compounds 
$2 \mathrm{~g}, 7$, and 8 (Figure 2a). For compound 5 , the increase in cytotoxicity in the presence of topotecan was significant only at the maximum concentration, $100 \mu \mathrm{M}$. For compound 6, the increase in cytotoxicity in the presence of topotecan (Figure 2a, cyan bars) was statistically insignificant. The cytotoxicity of the remaining compounds in the presence of topotecan did not change significantly (Figure 2b).

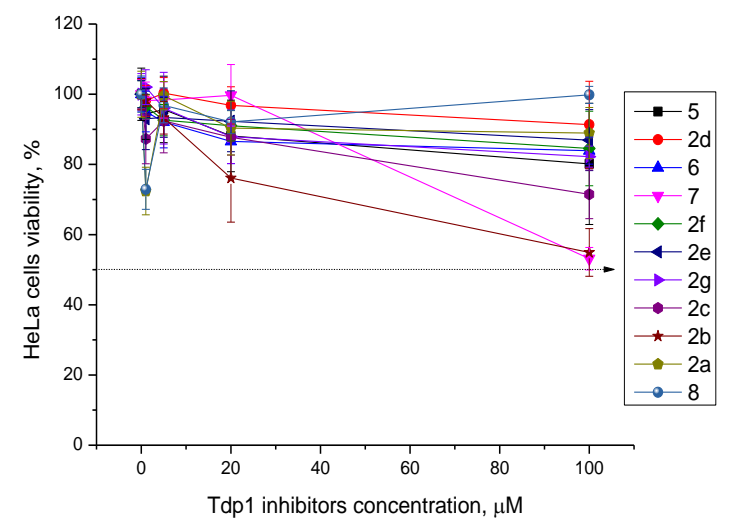

Figure 1. Dose-dependent action of the lipophilic pyrimidine nucleosides on HeLa cell viability measured in the EZ4U assay.

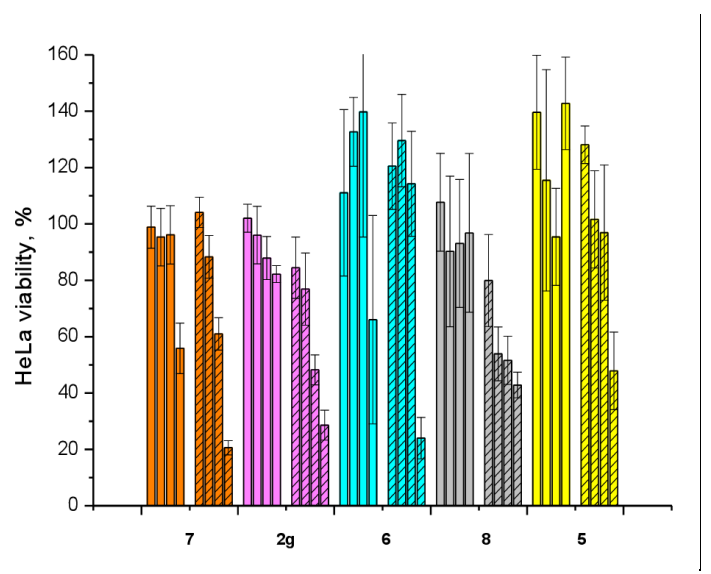

(a)

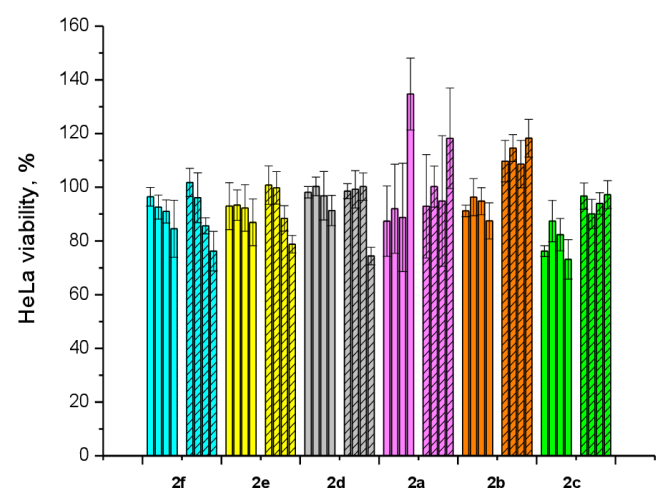

(b)

Figure 2. Dose-dependent action of the lipophilic nucleosides in combination with topotecan (Tpc) on HeLa cell viability in the EZ4U assay. The unshaded histogram bars denote cell viability in the presence of a single Tdp1 inhibitor. The hatched histogram bars indicate cell viability in the presence of a combination of a Tdp1 inhibitor with $2 \mu \mathrm{M}$ topotecan. (a) Compounds showing synergy with topotecan. The colors indicate: orange-compound 7 , magenta $-2 \mathrm{~g}$, cyan -6 , gray -8 , and yellow $-\mathbf{5}$. (b) Inactive compounds. The colors indicate: cyan-compound $\mathbf{2 f}$, yellow-2e, gray-2d, magenta-2a, orange-2 $\mathbf{b}$, and green-2c. Each of the four bars corresponds to an inhibitor concentration (from left to right) of $1,5,20$, and $100 \mu \mathrm{M}$. 
For the three compounds $\mathbf{2 g}, 7$, and 8 that had a synergistic effect with topotecan, a nontoxic concentration, $20 \mu \mathrm{M}$, which exerted a noticeable synergistic effect, was chosen for further experiments on HeLa cells at various doses of topotecan (Figure 3).

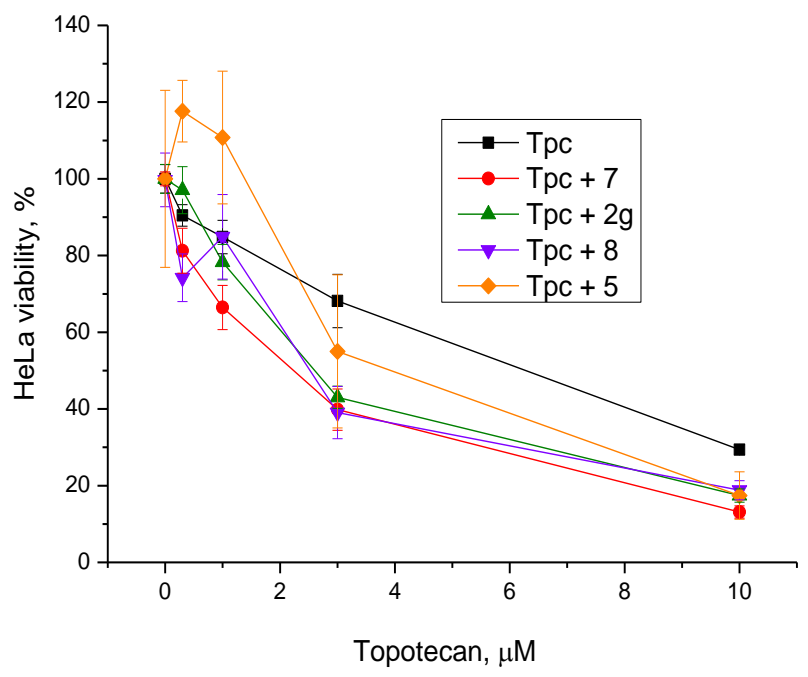

Figure 3. Dose-dependent action of topotecan (Tpc) in combination with one of the nucleoside derivatives on HeLa cell viability in the EZ4U assay.

For 5, a low cytotoxic concentration, $50 \mu \mathrm{M}$, was chosen because at a concentration of $20 \mu \mathrm{M}$, no synergy with topotecan was observed (Figure 2a, yellow bars). Compound 5 had a weak sensitizing effect on topotecan-treated cells at high concentrations (a significant effect at $10 \mu \mathrm{M}$; Figure 3, the orange graph compared to the black one). Compounds $\mathbf{2 g}, \mathbf{7}$, and $\mathbf{8}$ doubled the cytotoxicity of topotecan.

\section{Discussion}

It has been shown earlier that disaccharide nucleosides with lipophilic groups inhibit Tdp1 in a submicromolar range of concentrations and are only weakly toxic to cancerous and healthy cells [19]. On the other hand, disaccharide nucleosides tend to inhibit PARP1 [20,22], and this activity may reduce their selectivity toward Tdp1 in the cell. Therefore, we focused on nucleoside inhibitors of Tdp1, which are structurally modified previously described disaccharide inhibitors of Tdp1. New efficient Tdp1 inhibitors were found in a series of ribofuranose nucleoside derivatives and have $\mathrm{IC}_{50}$ values in the low micromolar and submicromolar range (Table 1). It was demonstrated here that for the manifestation of an inhibitory effect, the presence of the 2,3,5-tri-O-benzoyl- $\beta$-D-ribofuranose (2,3,5-tri-O-Bz- $\beta$-D-Rib) residue is necessary. Pyrimidine nucleosides (uridine, 5-fluorouridine, 5-chlorouridine, 5-bromouridine, 5-iodouridine, and ribothymidine) without lipophilic groups did not inhibit $\mathrm{Tdp} 1\left(\mathrm{IC}_{50}>50 \mu \mathrm{M}\right)$.

According to the calculations of the coefficient of distribution $(\log P)$ between the 1-octanol-water phases, the introduction of benzoyl groups (Bz) into pyrimidine nucleosides led to an increase in $\log \mathrm{P}$ and therefore could improve their penetration of cellular and nuclear membranes (Table 1). The magnitude of Tdp1 inhibition by the modified uridine nucleosides linearly correlated with the increase in $\log \mathrm{P}$ (Figure 4 and Supplementary Materials S18).

The presence of the bulky 2,3,5-tri-O-Bz- $\beta$-D-Rib residue significantly enhanced the inhibitory activity $\left(\mathrm{IC}_{50}=6.3 \mu \mathrm{M}\right.$ for $2^{\prime}, 3^{\prime}, 5^{\prime}$-tri-O-benzoyluridine $2 \mathrm{a}$ and $0.6 \mu \mathrm{M}$ for $2^{\prime}, 3^{\prime}, 5^{\prime}$-tri-O-benzoyl5-iodouridine 2d) in comparison with nucleoside derivatives lacking benzoyl groups (Table 1). 1-O-acetyl-2,3,5-tri-O-Bz- $\beta$-D-Rib (9) exerted a Tdp1-inhibitory activity similar to that of $O$-benzoylated cytidine (8) derivatives and a higher Tdp1-inhibitory activity than that of $O$-benzoylated uridine (2a), 5 -fluorouridine (2b), and pyrimidone (5 and $\mathbf{6}$ ) derivatives (Table 1). Most of these compounds were found to be characterized by $\operatorname{lower} \log \mathrm{P}$ than that of ribofuranose derivative 9 (Table $1, \log \mathrm{P}=5.62$ ). O-benzoylated uridine derivatives with $\log \mathrm{P}$ comparable to or higher than 5.62 manifested a higher 
Tdp1-inhibitory activity in comparison with a ribofuranose derivative (9). A decrease in the number of benzoic acid residues caused a marked decline in the inhibitory activity (Figure 5, $\mathrm{IC}_{50}=23 \mu \mathrm{M}$ for $2^{\prime}, 3^{\prime}$-di-O-benzoyluridine $4 \mathbf{a}$ and $\mathrm{IC}_{50}>100 \mu \mathrm{M}$ for $5^{\prime}$-O-benzoyluridine $3 \mathrm{a}$ ).

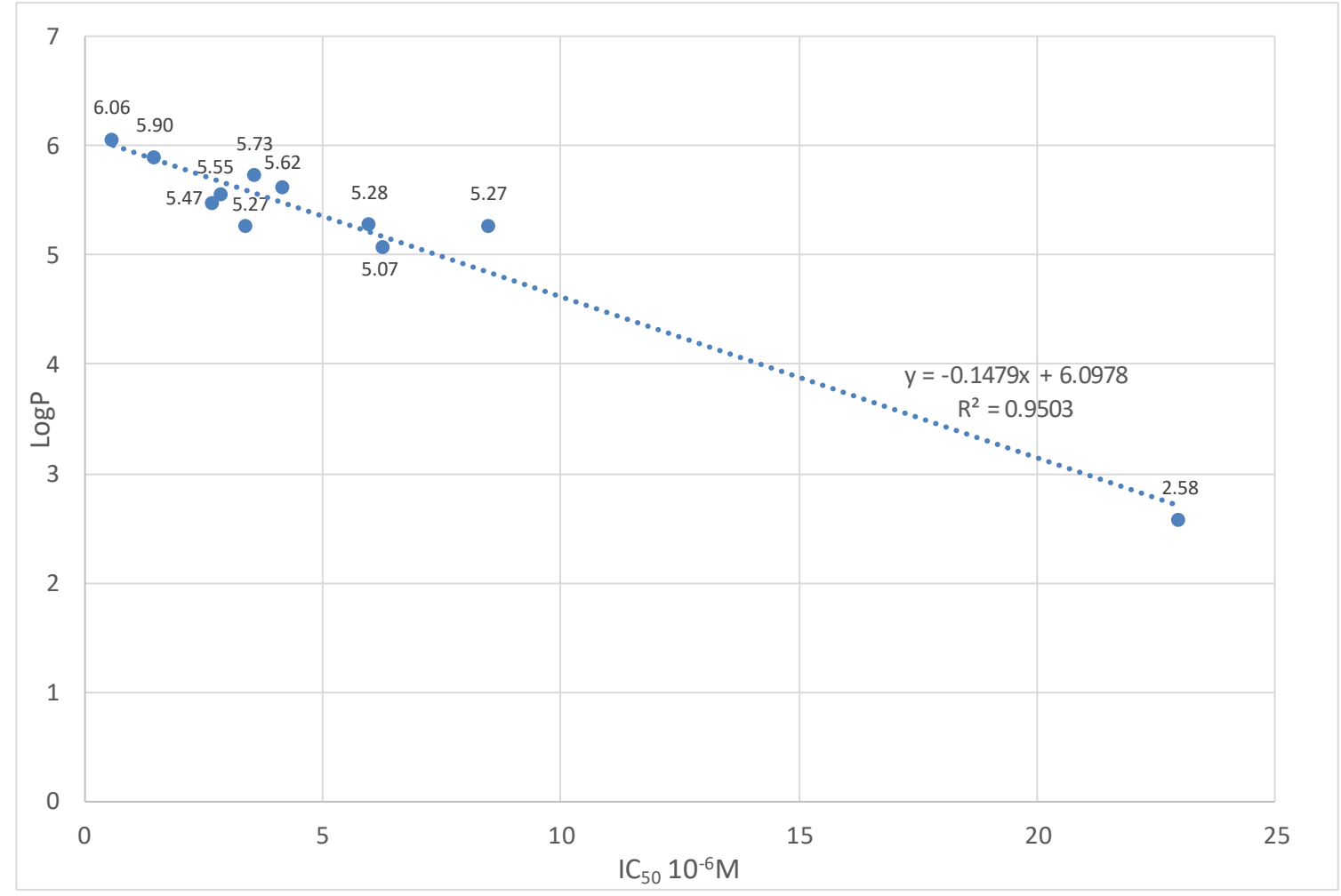

Figure 4. Correlation diagram between $\mathrm{Tdp}-1$ inhibition $\mathrm{IC}_{50}$ and $\log \mathrm{P}$ of nucleoside derivatives for compounds $2 a-2 g, 4 a, 6-7$ and 9 with exclusion of the data for compounds 5,8 .

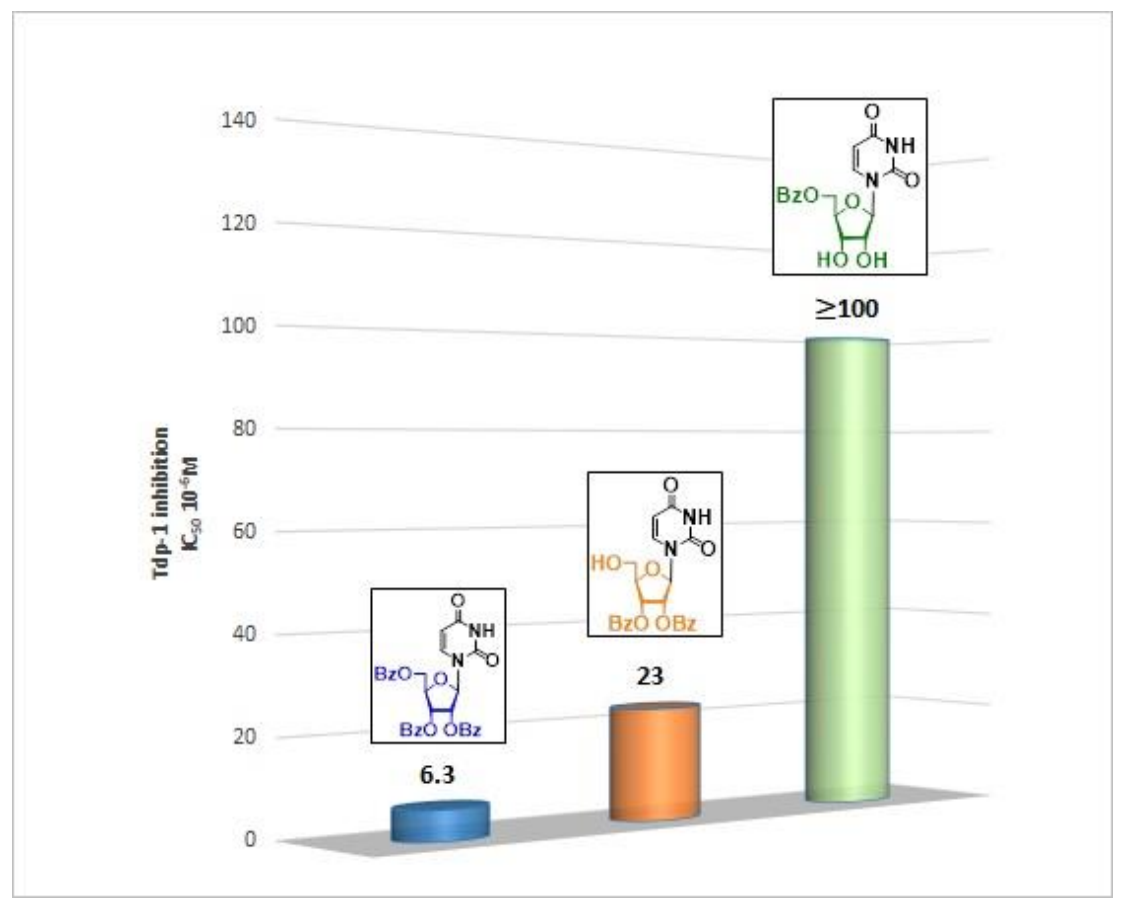

Figure 5. Structure-activity relationship between Tdp-1 inhibition and the quantity of benzoyl groups in nucleoside ribofuranose moiety. 
Thus, it can be claimed that lipophilicity and the number of benzoyl groups in the modified nucleoside compounds strongly influence Tdp1 inhibition.

It has been previously reported that disaccharide nucleosides $[20,22]$ and nucleoside derivatives with modified nitrogen bases $[29,30]$ inhibit PARP1. Therefore, in addition to the effect on Tdp1, a possible effect of the lipophilic nucleosides on DNA break sensors PARP1 and PARP2 was tested. Our compounds had virtually no impact on the activity of either enzyme (residual activity in the presence of each $1 \mathrm{mM}$ substance was 50-100\%), and therefore may be employed for the development of selective nucleoside inhibitors of Tdp1.

Several papers have been published in the past decade on the applicability of Tdp1 inhibitors for the sensitization of tumors to the action of anticancer topoisomerase 1 inhibitors (e.g., topotecan) see reviews $[3,4,17]$. Therefore, on HeLa cells, we also studied the effect of the synthesized Tdp1 inhibitors in combination with topotecan, which is the Top1 poison used in clinical practice. Given that Tdp1 inhibitors are supposed to be used in therapeutic cocktails, it is important that they do not exert their own toxicity and do not enhance the existing adverse effects of cancer therapy. According to the experiments on the viability of HeLa cells in the presence of the synthesized pyrimidine lipophilic nucleosides, the intrinsic cytotoxicity of the compounds was either absent or negligible at concentrations up to $100 \mu \mathrm{M}$ (Figure 1). The enhanced cytotoxicity of topotecan in the presence of the synthesized compounds was then studied. Four nucleoside compounds $(2 g, 5,7$, and 8$)$ each enhanced the cytotoxicity of a $2 \mu \mathrm{M}$ topotecan solution (Figure 2a), while the cytotoxicity of topotecan in the presence of the other compounds did not significantly change (Figure 2b). It was shown that compounds 7 (containing a 6-methoxy-2-oxopyrimidine residue), $2 \mathrm{~g}$ (containing a 6-methyluracil residue), and cytosine derivative 8 at a nontoxic concentration, $20 \mu \mathrm{M}$, have a sensitizing effect on topotecan-treated cells, thereby doubling topotecan's activity toward HeLa cells (Figure 3). These results suggest that nucleoside compounds containing a 2,3,5-tri-O-Bz- $\beta$-D-Rib group and a uracil base modified at positions 4 or 6 can penetrate into a cell nucleus and accumulate in it.

Tdp1 was discovered because of its ability to hydrolyze the stalled covalent 3 '-phospho-tyrosyl that represents the chemical linkage between the active-site tyrosine of DNA topoisomerase I (Topo1) and DNA [31-33]. The list of substrates of Tdp1 has since grown and consists of protein-DNA adducts, such as camptothecin-stabilized Topo1-DNA adducts, and modified nucleotides, including oxidized nucleotides, apurinic/apyrimidinic sites, and chain-terminating nucleoside analogs reviewed in [17] and described in [18,34]. Because many substrates of Tdp1 arise when anticancer and antiretroviral drugs are used, this enzyme is becoming an important therapeutic target. In addition, a natural catalytic-site Tdp1 mutant increases the stability of a Tdp1-DNA reaction intermediate and forms the molecular basis for an autosomal recessive neurodegenerative disease called spinocerebellar ataxia with axonal neuropathy (SCAN1).

A number of studies confirmed the hypothesis that Tdp1 is responsible for the resistance of some types of cancer to these drugs [35]: Tdp1-deficient human cells are hypersensitive to camptothecin [36-38]. Furthermore, recent data indicate that suppression of Tdp1 expression by minocycline enhances the antimetastatic effect of irinotecan and increases the life span of experimental animals [39]. Conversely, in cells with increased Tdp1 expression, camptothecin and etoposide cause less DNA damage $[40,41]$. Moreover, the response to irinotecan therapy is lower in tumors of the intestine with overexpression of Tdp1 [42]. Thus, it is expected that a combination of anticancer drugs and Tdp1 inhibitors can significantly increase the effectiveness of chemotherapy.

\section{Materials and Methods}

\subsection{General}

The solvents and materials were reagent grade and were used without additional purification. Column chromatography was performed on silica gel (Kieselgel 60, 0.040-0.063 mm, Merck, Darmstadt, Germany. Thin-layer chromatography was carried out on Alugram SIL G/UV254 (Macherey-Nagel, 
Düren, Germany) with UV visualization. Melting points were determined by means of Electrothermal Melting Point Apparatus IA6301 and are uncorrected. ${ }^{1} \mathrm{H}$ and ${ }^{13} \mathrm{C}$ (with complete proton decoupling) NMR spectra were recorded on a Bruker AMX 400 NMR instrument (Bruker, Billerica, MA, USA). ${ }^{1} \mathrm{H}-\mathrm{NMR}$-spectra were acquired at $400 \mathrm{MHz}$, and ${ }^{13} \mathrm{C}-\mathrm{NMR}$ spectra at $100 \mathrm{MHz}$. Chemical shifts in parts per million (ppm) were measured relative to the residual solvent signals as internal standards $\left(\mathrm{CDCl}_{3},{ }^{1} \mathrm{H}\right.$ : $7.26 \mathrm{ppm},{ }^{13} \mathrm{C}: 77.1 \mathrm{ppm}$; DMSO- $d_{6},{ }^{1} \mathrm{H}: 2.50 \mathrm{ppm}$, and $\left.{ }^{13} \mathrm{C}: 39.5 \mathrm{ppm}\right)$. Spin-spin coupling constants $(J)$ are given in Hertz $(\mathrm{Hz})$. The following compounds were prepared according to the methods reported earlier: compounds $\mathbf{2 a - e ~ [ 2 6 ] , ~ 2 f ~ [ 4 3 ] , ~ c o m p o u n d ~} \mathbf{2 g}$ [44], and derivatives of pyrimidine-4-one, pyrimidine-2-one, 2-oxo-4-methoxypyrimidine (5-7) [25,44,45], and of $2^{\prime}, 3^{\prime}, 5^{\prime}$-tri-O-benzoylcytidine (8) [26]. The compounds' coefficients of partition between the octanol-water phases $(\log P)$ were calculated in the Instant J. Chem. (ChemAxon ${ }^{\circledR}$ ) software (Budapest, Hungary).

\subsection{Real-Time Detection of Tdp1 Activity}

This procedure was reported in our previous work [27]. The approach consists of fluorescence intensity measurement in a reaction of quencher removal from a fluorophore quencher-coupled DNA oligonucleotide catalyzed by Tdp1 in the presence of an inhibitor (the control samples contained $1 \%$ of DMSO). The reaction mixtures $(200 \mu \mathrm{L})$ contained Tdp1 buffer $(50 \mathrm{mM}$ Tris- $\mathrm{HCl} \mathrm{pH} 8.0,50 \mathrm{mM} \mathrm{NaCl}$, and $7 \mathrm{mM} \beta$-mercaptoethanol), $50 \mathrm{nM}$ biosensor, an inhibitor being tested, and purified Tdp1 (1.5 nM). The biosensor was a single-stranded oligonucleotide (5'-[FAM] AAC GTC AGGGTC TTC C [BHQ]-3') containing a fluorophore at the $5^{\prime}$ end (5,6-FAM) and Black Hole Quencher 1 (BHQ) at the $3^{\prime}$ end and was synthesized in the Laboratory of Biomedical Chemistry at the Institute of Chemical Biology and Fundamental Medicine (Novosibirsk, Russia).

The reactions were incubated at a constant temperature of $26{ }^{\circ} \mathrm{C}$ on a POLARstar OPTIMA fluorimeter (BMG LABTECH, GmbH, Ortenberg, Germany) to measure fluorescence every $55 \mathrm{~s}$ (ex. 485/em. $520 \mathrm{~nm}$ ) during the linear phase (here, data from minute 0 to minute 8 ). The values of $\mathrm{IC}_{50}$ were determined using a six-point concentration response curve in three independent experiments and were calculated using MARS Data Analysis 2.0 (BMG LABTECH).

\subsection{Cell Culture Assays}

Intrinsic toxicity of the compounds to human cell line HeLa (cervical cancer) was examined by means of the EZ4U Cell Proliferation and Cytotoxicity Assay (Biomedica, Wien, Austria), according to the manufacturer's protocols. The cells were grown in Iscove's modified Dulbecco's medium (IMDM) with $40 \mu \mathrm{g} / \mathrm{mL}$ gentamicin, $50 \mathrm{IU} / \mathrm{mL}$ penicillin, $50 \mu \mathrm{g} / \mathrm{mL}$ streptomycin (MP Biomedicals), and 10\% of fetal bovine serum (Biolot) in a $5 \% \mathrm{CO}_{2}$ atmosphere. After formation of a 30-50\%-confluent monolayer, one of the tested compounds was added to the medium (the volume of the added reagents was 1/100 of the total volume of the culture medium, and the amount of DMSO was $1 \%$ of the final volume), and the cell culture was monitored for 3 days. Control cells were grown in the presence of $1 \%$ DMSO. To assess the influence of the inhibitors on the cytotoxic effect of topotecan, the latter from the manufacturer ACTAVIS GROUP PTC ehf. (Bucharest, Romania) was used. First of all, 50\% cytotoxic concentrations of topotecan and of each inhibitor were determined to attain a defined single-agent effect. Second, three independent tests were performed with each inhibitor in combination with topotecan.

\section{Conclusions}

We studied the inhibition of DNA repair enzymes (PARP1, PARP2, and Tdp1) by lipophilic pyrimidine nucleosides. New effective Tdp1 inhibitors were found in a series of lipophilic pyrimidine nucleosides and have $\mathrm{IC}_{50}$ in the lower micromolar and submicromolar range. The 2,3,5-tri-O-Bz- $\beta$-D-Rib moiety appears to be the pharmacophore that is essential for Tdp1 inhibition by each synthesized compound. It was shown that the lipophilic pyrimidine nucleosides inhibiting Tdp1 in vitro have only low cytotoxicity. Some derivatives strengthen the action of topotecan on HeLa cells and thus may be 
considered promising for further optimization of the structure and the development of compounds sensitizing cancer cells to topotecan.

\section{Patents}

The application for RU patent №2019141448 was registered 13.12.2019.

Supplementary Materials: The following are available online, Figure S1: ${ }^{1} \mathrm{H}-\mathrm{NMR}$-spectrum $(400 \mathrm{MHz})$ of $2^{\prime}, 3^{\prime}, 5^{\prime}$-tri-O-benzoyluridine in DMSO- $d_{6}$ at $298 \mathrm{~K}$, Figure S2: ${ }^{13} \mathrm{C}-\mathrm{NMR}$-spectrum $(400 \mathrm{MHz})$ of $2^{\prime}, 3^{\prime}, 5^{\prime}$-tri-O-benzoyluridine in DMSO- $d_{6}$ at $298 \mathrm{~K}$, Figure S3: ${ }^{1} \mathrm{H}$-NMR-spectrum $(400 \mathrm{MHz})$ of 5-fluoro-2 $2^{\prime}, 3^{\prime}, 5^{\prime}$-tri-O-benzoyluridine in DMSO- $d_{6}$ at $298 \mathrm{~K}$, Figure S4: ${ }^{13} \mathrm{C}-\mathrm{NMR}$-spectrum $(100 \mathrm{MHz})$ of 5-fluoro- $2^{\prime}, 3^{\prime}, 5^{\prime}$-tri-O-benzoyluridine in DMSO- $d_{6}$ at $298 \mathrm{~K}$, Figure S5: ${ }^{1} \mathrm{H}-\mathrm{NMR}$-spectrum $(400 \mathrm{MHz})$ of 5-chloro-2 $2^{\prime}, 3^{\prime}, 5^{\prime}$-tri-O-benzoyluridine in DMSO- $d_{6}$ at $298 \mathrm{~K}$, Figure S6: ${ }^{13} \mathrm{C}-\mathrm{NMR}$-spectrum $(100 \mathrm{MHz})$ of 5-chloro-2 $2^{\prime}, 3^{\prime}, 5^{\prime}$-tri-O-benzoyluridine in DMSO- $d_{6}$ at $298 \mathrm{~K}$, Figure S7: ${ }^{1} \mathrm{H}-\mathrm{NMR}$-spectrum $(400 \mathrm{MHz})$ of 5-bromo- $2^{\prime}, 3^{\prime}, 5^{\prime}$-tri-O-benzoyluridine in DMSO- $d_{6}$ at $298 \mathrm{~K}$, Figure S8: ${ }^{13} \mathrm{C}$-NMR-spectrum $(100 \mathrm{MHz})$ of 5-bromo- $2^{\prime}, 3^{\prime}, 5^{\prime}$-tri-O-benzoyluridine in DMSO- $d_{6}$ at $298 \mathrm{~K}$, Figure S9: ${ }^{1} \mathrm{H}$-NMR-spectrum $(400 \mathrm{MHz})$ of 5-iodo-2 ${ }^{\prime}, 3^{\prime}, 5^{\prime}$-tri-O-benzoyluridine in DMSO- $d_{6}$ at $298 \mathrm{~K}$, Figure S10: ${ }^{13} \mathrm{C}-\mathrm{NMR}$-spectrum $(100 \mathrm{MHz})$ of 5-iodo-2', $3^{\prime}, 5^{\prime}$-tri-O-benzoyluridine in $\mathrm{CDCl}_{3}$ at $298 \mathrm{~K}$, Figure $\mathrm{S} 11:{ }^{1} \mathrm{H}$-NMR-spectrum $(400 \mathrm{MHz})$ of $2^{\prime}, 3^{\prime}, 5^{\prime}$-tri-O-benzoylribotimidine in DMSO- $d_{6}$ at $298 \mathrm{~K}$, Figure S12: ${ }^{13} \mathrm{C}-\mathrm{NMR}$-spectrum $(100 \mathrm{MHz})$ of $2^{\prime}, 3^{\prime}, 5^{\prime}$-tri-O-benzoylribotimidine in DMSO- $d_{6}$ at $298 \mathrm{~K}$, Figure S13: ${ }^{1} \mathrm{H}$-NMR-spectrum $(400 \mathrm{MHz})$ of $2^{\prime}, 3^{\prime}, 5^{\prime}$-tri-O-benzoylcytidine in DMSO- $d_{6}$ at $298 \mathrm{~K}$, Figure S14: ${ }^{13} \mathrm{C}-\mathrm{NMR}$-spectrum $(100 \mathrm{MHz})$ of $2^{\prime}, 3^{\prime}, 5^{\prime}$-tri-O-benzoylcytidine in DMSO- $d_{6}$ at $298 \mathrm{~K}$, Table S1: Inhibition of Tdp- 1 by nucleoside derivatives, Figure S15: Dose-dependent action of the lipophilic pyrimidine nucleosides on HeLa cell viability measured in the EZ4U assay, Figure S16: Dose-dependent action of the lipophilic nucleosides in combination with topotecan (Tpc) on HeLa cell viability in the EZ4U assay, Figure S17: Dose-dependent action of topotecan (Tpc) in combination with one of the nucleoside derivatives on HeLa cell viability in the EZ4U assay, Figure S18: Correlation diagram between Tdp-1 inhibition $\mathrm{IC}_{50}$ and $\log \mathrm{P}$ of nucleoside derivatives for compounds $\mathbf{2 a - 2 g}, \mathbf{4 a}, \mathbf{5 - 9}$, Figure S19: Structure-activity relationship between Tdp-1 inhibition and the quantity of benzoyl groups in nucleoside ribofuranose moiety.

Author Contributions: Conceptualization, S.N.M. and O.I.L.; methodology, A.L.Z., N.S.D. and M.S.D.; investigation, A.L.Z., M.S.D., N.S.D., G.A.I., E.S.I., I.A.C.; data analysis, A.L.Z., M.S.D., N.S.D., V.E.O.; writing-original draft preparation, A.L.Z., M.S.D., V.E.O.; writing-review and editing, S.N.M. and O.I.L.; supervision, S.N.M.; project administration, S.N.M.; funding acquisition, S.N.M. All authors have read and agreed to the published version of the manuscript.

Funding: This research was funded by RUSSIAN FOUNDATION FOR BASIC RESEARCH (RFBR), grant number 18-29-09037.

Acknowledgments: We thank Juliana Raikova, a student of Moscow Institute of Fine Chemical Technology (MITHT), for assistance in chemical synthesis of nucleoside compounds.

Conflicts of Interest: The authors declare no conflict of interest.

\section{Abbreviations}

MDPI Multidisciplinary Digital Publishing Institute

DOAJ Directory of open access journals

\section{References}

1. Hosoya, N.; Miyagawa, K. Targeting DNA damage response in cancer therapy. Cancer Sci. 2014, 105, 370-388. [CrossRef] [PubMed]

2. Laev, S.S.; Salakhutdinov, N.F.; Lavrik, O.I. Tyrosyl-DNA phosphodiesterase inhibitors: Progress and potential. Bioorg. Med. Chem. 2016, 24, 5017-5027. [CrossRef] [PubMed]

3. Brettrager, E.J.; van Waardenburg, R.C.A.M. Targeting tyrosyl-DNA phosphodiesterase I to enhance toxicity of phosphodiester linked DNA adducts. Cancer Drug Resist 2019, 2. [CrossRef] [PubMed]

4. Zakharenko, A.; Dyrkheeva, N.; Lavrik, O. Dual DNA topoisomerase 1 and tyrosyl-DNA phosphodiesterase 1 inhibition for improved anticancer activity. Med. Res. Rev. 2019, 39, 1427-1441. [CrossRef]

5. Kelley, M.R.; Logsdon, D.; Fishel, M.L. Targeting DNA repair pathways for cancer treatment: What's new? Future Oncol. 2014, 10, 1215-1237. [CrossRef] 
6. Francica, P.; Rottenberg, S. Mechanisms of PARP inhibitor resistance in cancer and insights into the DNA damage response. Genome Med. 2018, 10, 101. [CrossRef]

7. Matsuno, Y.; Hyodo, M.; Fujimori, H.; Shimizu, A.; Yoshioka, K.I. Sensitization of cancer cells to radiation and topoisomerase I inhibitor camptothecin using inhibitors of PARP and other signaling molecules. Cancers 2018, 10, 364. [CrossRef]

8. Minchom, A.; Aversa, C.; Lopez, J. Dancing with the DNA damage response: Next-generation anti-cancer therapeutic strategies. Ther. Adv. Med. Oncol. 2018, 10. [CrossRef]

9. Rouleau, M.; Patel, A.; Hendzel, M.J.; Kaufmann, S.H.; Poirier, G.G. PARP inhibition: PARP-1 and beyond. Nat. Rev. 2010, 10, 293-301. [CrossRef]

10. Drenichev, M.S.; Mikhailov, S.N. Poly(ADP-ribose)-a unique natural polymer. Structural features, biological role and approaches to the chemical synthesis. Nucleosides Nucleot. Nucl. Acids 2015, 34, 258-276. [CrossRef]

11. Drenichev, M.S.; Mikhailov, S.N. Poly(ADP-ribose): From chemical synthesis to drug design. Digest paper. Bioorg. Med. Chem. Lett. 2016, 26, 3395-3403. [CrossRef] [PubMed]

12. Curtin, N.J. Inhibiting the DNA damage response as a therapeutic manoeuvre in cancer. Br. J. Pharmacol. 2013, 169, 1745-1765. [CrossRef] [PubMed]

13. Moor, N.A.; Lavrik, O.I. Protein-protein interactions in DNA base excision repair. Biochemistry (Moscow) 2018, 83, 411-422. [CrossRef] [PubMed]

14. Bhattacharjee, S.; Nandi, S. Rare Genetic Diseases with Defects in DNA Repair: Opportunities and Challenges in Orphan Drug Development for Targeted Cancer Therapy. Cancers 2018, 10, 298. [CrossRef] [PubMed]

15. Bhattacharjee, S.; Nandi, S. DNA damage response and cancer therapeutics through the lens of the Fanconi Anemia DNA repair pathway. Cell Commun. Signal. 2017. [CrossRef]

16. Ferraris, D.V. Evolution of poly(ADP-ribose) polymerase-1 (PARP-1) inhibitors. From concept to clinic. J. Med. Chem. 2010, 53, 4561-4584. [CrossRef]

17. Comeaux, E.Q.; Waardenburg, R.C. Tyrosyl-DNA phosphodiesterase I resolves both naturally and chemically induced DNA adducts and its potential as a therapeutic target. Drug Metab Rev. 2014, 46, 494-507. [CrossRef]

18. Rechkunova, N.I.; Lebedeva, N.A.; Lavrik, O.I. Tyrosyl-DNA phosphodiesterase Tdp1 is a new player in repair of apurinic/apirimidinic sites in DNA. Rus. J. Bioorg. Chem. 2015, 41, 474-480. [CrossRef]

19. Komarova, A.O.; Drenichev, M.S.; Dyrkheeva, N.S.; Kulikova, I.V.; Oslovsky, V.E.; Zakharova, O.D.; Zakharenko, A.L.; Mikhailov, S.N.; Lavrik, O.I. Novel group of tyrosyl-DNA-phosphodiesterase 1 inhibitors based on disaccharide nucleosides as drug prototypes for anti-cancer therapy. J. Enz. Inh. Med. Chem. 2018, 33, 1415-1429. [CrossRef]

20. Efremova, A.S.; Zakharenko, A.L.; Shram, S.I.; Kulikova, I.V.; Drenichev, M.S.; Sukhanova, M.V.; Khodyreva, S.N.; Myasoedov, N.F.; Lavrik, O.I.; Mikhailov, S.N. Disaccharide pyrimidine nucleosides and their derivatives: A novel group of cell-penetrating inhibitors of poly(ADP-ribose) polymerase-1. Nucleosides Nucleot. Nucl. Acids 2013, 32, 510-528. [CrossRef]

21. Mikhailov, S.N.; Efimtseva, E.V.; Rodionov, A.A.; Bobkov, G.V.; Kulikova, I.V.; Herdewijn, P. Synthesis of 2-O- $\beta$-D-ribofuranosylnucleosides. Curr. Prot. Nucl. Acids Chem. 2006, 27, 1.14.1-1.14.18. [CrossRef] [PubMed]

22. Efremova, A.S.; Shram, S.I.; Drenichev, M.S.; Posypanova, G.A.; Myasoedov, N.F.; Mikhailov, S.N. The selective toxic effect of dialdehyde derivatives of pyrimidine nucleosides on human ovarian cancer cells. Biochem. (Moscow) Suppl. Ser. B Biomed. Chem. 2014, 8, 318-322. [CrossRef]

23. Mikhailov, S.N.; Kulikova, I.V.; Nauwelaerts, K.; Herdewijn, P. Synthesis of 2'-O- $\alpha$-D-ribofuranosyladenosine, monomeric unit of poly(ADP-ribose). Tetrahedron 2008, 64, 2871-2876. [CrossRef]

24. Mikhailov, S.N.; Drenichev, M.S.; Oslovsky, V.E.; Kulikova, I.V.; Herdewijn, P. Synthesis of poly(ADP-ribose) monomer containing 2'-O- $\alpha$-D-ribofuranosyl adenosine. Curr. Prot. Nucl. Acids Chem. 2019, e92. [CrossRef] [PubMed]

25. Vorbrüggen, H. Adventures in silicon-organic chemistry. Acc. Chem. Res. 1995, 28, 509-520. [CrossRef]

26. Prasad, A.K.; Kumar, V.; Malhotra, S.; Ravikumar, V.T.; Sanghvi, Y.S.; Parmar, V.S. 'Green' methodology for efficient and selective benzoylation of nucleosides using benzoyl cyanide in an ionic liquid. Bioorg. Med. Chem. 2005, 13, 4467-4472. [CrossRef] [PubMed]

27. Zakharenko, A.; Khomenko, T.; Zhukova, S.; Koval, O.; Zakharova, O.; Anarbaev, R.; Lebedeva, N.; Korchagina, D.; Komarova, N.; Vasiliev, V.; et al. Synthesis and biological evaluation of novel tyrosyl-DNA phosphodiesterase 1 inhibitors with a benzopentathiepine moiety. Bioorg. Med. Chem. 2015, 23, 2044-2052. [CrossRef] 
28. Shimokawa, S.; Kimura, J.; Mitsunobu, O. Studies on nucleosides and nucleotides. V. Selective aroylation of 5'-hydroxyl group of uridine and adenosine. Bull. Chem. Soc. Jpn. 1976, 49, 3357-3358. [CrossRef]

29. Preiss, J.; Schlaeger, R.; Hilz, H. Specific inhibition of poly ADP-ribose polymerase by thymidine and nicotinamide in HeLa cells. FEBS Lett. 1971, 19, 244-246. [CrossRef]

30. Pivazyan, A.D.; Birks, E.M.; Wood, T.G.; Lin, T.S.; Prusoff, W.H. Inhibition of poly(ADP-ribose)polymerase activity by nucleoside analogs of thymidine. Biochem. Pharmacol. 1992, 44, 947-953. [CrossRef]

31. Pouliot, J.J.; Robertson, C.A.; Nash, H.A. Pathways for repair of topoisomerase I covalent complexes in Saccharomyces cerevisiae. Genes Cells 2001, 6, 677-687. [CrossRef] [PubMed]

32. Pouliot, J.J.; Yao, K.C.; Robertson, C.A.; Nash, H.A. Yeast gene for a Tyr-DNA phosphodiesterase that repairs topoisomerase I complexes. Science 1999, 286, 552-555. [CrossRef] [PubMed]

33. Yang, S.W.; Burgin, A.B., Jr.; Huizenga, B.N.; Robertson, C.A.; Yao, K.C.; Nash, H.A. A eukaryotic enzyme that can disjoin dead-end covalent complexes between DNA and type I topoisomerases. Proc. Natl. Acad. Sci. USA 1996, 93, 11534-11539. [CrossRef] [PubMed]

34. Interthal, H.; Chen, H.J.; Champoux, J.J. Human Tdp1 cleaves a broad spectrum of substrates, including phosphoamide linkages. J. Biol. Chem. 2005, 280, 36518-36528. [CrossRef]

35. Beretta, G.L.; Cossa, G.; Gatti, L.; Zunino, F.; Perego, P. Tyrosyl-DNA phosphodiesterase 1 targeting for modulation of camptothecin-based treatment. Curr. Med. Chem. 2010, 17, 1500-1508. [CrossRef]

36. Interthal, H.; Chen, H.J.; Kehl-Fie, T.; Zotzmann, J.; Leppard, J.; Champoux, J. SCAN1 mutant Tdp1 accumulates the enzyme-DNA intermediate and causes camptothecin hypersensitivity. EMBO J. 2005, 24, 2224-2233. [CrossRef]

37. El-Khamisy, S.; Saifi, G.; Weinfeld, M.; Johansson, F.; Helleday, T.; Lupski, J.; Caldecott, K. Defective DNA single-strand break repair in spinocerebellar ataxia with axonal neuropathy-1. Nature 2005, 434, 108-113. [CrossRef]

38. Miao, Z.-H.; Agama, K.; Sordet, O.; Povirk, L.; Kohn, K.; Pommier, Y. Hereditary ataxia SCAN1 cells are defective for the repair of transcription-dependent topoisomerase I cleavage complexes. DNA Repair 2006, 5, 1489-1494. [CrossRef]

39. Huang, H.-C.; Liu, J.; Baglo, Y.; Rizvi, I.; Anbil, S.; Pigula, M.; Hasan, T. Mechanism-informed Repurposing of Minocycline Overcomes Resistance to Topoisomerase Inhibition for Peritoneal Carcinomatosis. Mol. Cancer Ther. 2018, 17, 508-520. [CrossRef]

40. Nivens, M.C.; Felder, T.; Galloway, A.H.; Pena, M.M.O.; Pouliot, J.J.; Spencer, H.T. Engineered Resistance to Camptothecin and Antifolates by Retroviral Coexpression of Tyrosyl DNA phosphodiesterase-I and Thymidylate Synthase. Cancer Chemother. Pharmacol. 2004, 53, 107-115. [CrossRef]

41. Barthelmes, H.U.; Habermeyer, M.; Christensen, M.O.; Mielke, C.; Interthal, H.; Pouliot, J.J.; Boege, F.; Marko, D. TDP1 Overexpression in Human Cells Counteracts DNA Damage Mediated by Topoisomerases I and II. J. Biol. Chem. 2004, 279, 55618-55625. [CrossRef] [PubMed]

42. Meisenberg, C.; Gilbert, D.; Chalmers, A.; Haley, V.; Gollins, S.; Ward, S.; El-Khamisy, S. Clinical and cellular roles for TDP1 and TOP1 in modulating colorectal cancer response to irinotecan. Mol. Cancer Ther. 2015, 14, 575-585. [CrossRef] [PubMed]

43. Van Aerschot, A.; Everaert, D.; Balzarini, J.; Augustyns, K.; Jie, L.; Janssen, G.; Peeters, O.; Blaton, N.; De Ranter, C.; De Clercq, E.; et al. Synthesis and anti-HIV evaluation of 2' $3^{\prime}$-dideoxyribo-5-chloropyrimidine analogues: Reduced toxicity of 5-chlorinated 2', $3^{\prime}$-dideoxynucleosides. J. Med. Chem. 1990, 33, 1833-1839. [CrossRef] [PubMed]

44. Niedballa, U.; Vorbruggen, H. A general synthesis of N-glycosides. IV. Synthesis of nucleosides of hydroxyl and mercapto N-heterocycles. J. Org. Chem. 1977, 39, 3668-3671. [CrossRef]

45. Vorbrüggen, H.; Bennua, B. A new simplified nucleoside synthesis. Chem. Ber. 1981, 114, $1279-1286$. [CrossRef]

Sample Availability: Samples of the compounds 1-9 are available from the authors.

(C) 2020 by the authors. Licensee MDPI, Basel, Switzerland. This article is an open access article distributed under the terms and conditions of the Creative Commons Attribution (CC BY) license (http://creativecommons.org/licenses/by/4.0/). 